\title{
Never Used Oral Contraceptives
}

National Cancer Institute

\section{Source}

National Cancer Institute. Never Used Oral Contraceptives. NCI Thesaurus. Code C157413.

An individual who has never used oral contraceptives. 